Journal of Urban and Regional Analysis, vol. XII, 1, 2020, p. 19 - 33

https://doi.org/10.37043/JURA.2020.12.1.2

\title{
OPEN-SOURCE WEB GIS FRAMEWORK IN MONITORING URBAN LAND USE PLANNING: PARTICIPATORY SOLUTIONS FOR DEVELOPING COUNTRIES
}

\author{
Anang Wahyu SEJATI', Imam BUCHORI ${ }^{1}$, Iwan RUDIARTO ${ }^{1}$, \\ Christopher SILVER ${ }^{2}$, Kartiko SULISTYO ${ }^{1}$ \\ ${ }^{1}$ Diponegoro University, Semarang, Indonesia \\ ${ }^{2}$ University of Florida, Gainesville, United States of America
}

\begin{abstract}
This paper presents a Web GIS application development framework through an open-source software which aims to provide reliable open data services, required for policymaking in urban land use planning. The geodatabase model is comprehensively developed. It displayed a user interface using QGIS, MapServer, and Pmapper, with open source tools with PHP MapScript programming languages and integrated DB-SQL, to generate a complete digital map service with information on urban land use policy. The results of this Web GIS development can be publicly used with spatial databases suitable for public consumption, and as decision support systems for stakeholders, especially in the policy of urban land use planning. Thus, this application can serve as a model for land-use monitoring systems based upon the principle of information disclosure toward smart city and smart governance.
\end{abstract}

Key Words: web GIS, smart city, smart governance, urban land use planning.

\section{Introduction}

The current debates on what makes a smart city point to a wide array of factors. These include smart city factors like economy, mobility, environment, and governance, but one overriding factor is the extent to which information technology is integrated into primary urban functions (Gil-Garcia et al. 2016, Fietkiewicz et al. 2017, Lv et al. 2017). Claims about smart cities have been perceived as a market strategy to promote the influence of neoliberalism and distract from real problems in urban areas (Grossi and Pianezzi 2017). With considerable developments, the concept of smart cities has also affected developing countries such as Indonesia, which is now trying to realize that concept. Indeed, the realization of smart cities requires adequate preparation that will not only result in a utopian claim that a city is smart but will also benefit the people's quality of life (Kummitha and Crutzen 2017).

In recent studies, ten so-called smart cities, namely Tampere, Geneva, Seoul, New Songdo, Vienna, London, Washington DC, New York City, Hongkong and Melbourne, have shown the concept of open data for various development plans, as one of the principal aspects of being a smart city (Anthopoulos 2017). For open data to support smart people and smart governance, expensive information technology is required which must be adapted to the needs of the society. Although the concept of smart cities is not very utopian, it can be applied to resolving real problems in urban areas (Anthopoulos 2017, Grossi and Pianezzi 2017, Kim et al. 2017, Kummitha and Crutzen 2017). Moreover, open data also helps to educate people and the government, so it supports policymaking toward smart people and smart governance.

The principle of open data and information technology in realizing smart cities is crucial, and Geo-ICT (Aina 2017, Kim et al. 2017) is one such example. Geo-ICT helps us to understand urban issues and, in addition to its spatial potential, it is also highly informative (Buchori and Tanjung 2014, Buchori et al. 2015a, Purwanto and Bayuardi 2016, Aina 2017, Elmanisa et al. 
2017). Although information technology is not the only aspect embodied in the concept of smart cities (Kummitha and Crutzen 2017), it is crucial to support the existence of a smart city (Aina 2017, Kim et al. 2017, Niaros et al. 2017). One form of open data in Geo-ICT is web-based GIS or Web GIS. The concept of Web GIS is the ability to provide an overview of spatial information with spatial data that provides information to support decision making (Thiebes et al. 2013, Buchori et al. 2015b, Sejati and Ramadhan 2015). For developing countries, Web GIS can be produced by exploiting open-source softwares, so that the cost is cheaper, and the purpose of open data especially in delivering public policy can be achieved (Nakayama et al. 2017).

In the broader context, smart cities support sustainable cities, where in general the concept of smart cities is an improvisation of sustainable cities, with some strengthening in innovation and technology (Buchori and Sugiri 2016, Ahvenniemi et al. 2017, Buchori et al. 2018, Sejati et al. $2018,2019)$. Based on this statement, the strengthening of technology becomes very important for the realization of smart and sustainable cities. The technology in this paper is a technology that can realize the components of smart cities, one of which is smart governance.

Numerous studies on smart governance and ICT have focused on data acquisition for policymaking (Feltynowski 2015, Eom et al. 2016, Gil-Garcia et al. 2016, Fietkiewicz et al. 2017, Lv et al. 2017), the use of Web GIS for disaster information (Pessina and Meroni 2009, Nasaruddin et al. 2011, Dong et al. 2013, Thiebes et al. 2013, Fago et al. 2014), and policymaking in bridging the information gap between rural areas and civic education (Wirkus 2015, Müller et al. 2016, Stanković et al. 2016). The research to date has not focused on monitoring the implementation of infrastructure and urban land use policy, and so it has been unable to explain how the system is built based on real behaviors and problems with smart governance in urban infrastructure and land use management. To complement the previous studies, it is necessary to describe the development of Web GIS for policy-making following the characteristics of developing countries. On this basis, the purpose of this paper is to provide a framework for how the Open-Source Web GIS application can support decision making, especially in monitoring the implementation of land use policy in developing countries, particularly in Indonesia.

\section{Methodology}

\section{Study area}

The Web GIS framework in this research is applied in Balikpapan City, which is located in the fastest growing area in East Borneo (Fig. 1). In 2014, Balikpapan was named the most prosperous city by the 24th Eastern Regional Organization for Planning and Housing (EAROPH) Congress. The assessment was based on the Indonesian Most Livable City Index 2014. Besides, in 2015, Balikpapan also won an environmentally sustainable city award. With these achievements, Balikpapan has tried to develop the concept of a smart city by developing Web GIS as a decision support system, especially in infrastructure and spatial planning.

Economically, Balikpapan is large and growing due to its oil and gas industry, and the growth of the city and its infrastructure is supported by the success of this sector (Tarigan et al. 2017). In 2016, after several oil companies moved out from Balikpapan, the government wanted to be able to control post-oil industry changes, and so useful governance concepts in monitoring the implementation of spatial and infrastructure planning have become essential.

\section{Web GIS development}

Web GIS development uses several open-source components, such as Map-Server and Pmapper (Burger 2009). The open-source software model adjusts the purpose of making the system by defining layers and control layers (Gkatzoflias et al. 2013, Thiebes et al. 2013, Nakayama et al. 2017). The layer in Pmapper 
controls the attributes and the digital maps that appear in Web GIS. In this work, the required input data is a digital map of the Balikpapan area. Theoretically, the objects that exist in the space geography can be divided into two types of information. The first type is in accordance with the location on Earth, known as spatial data. The second type identifies the non-spatial property of the object and it is called the attribute data.

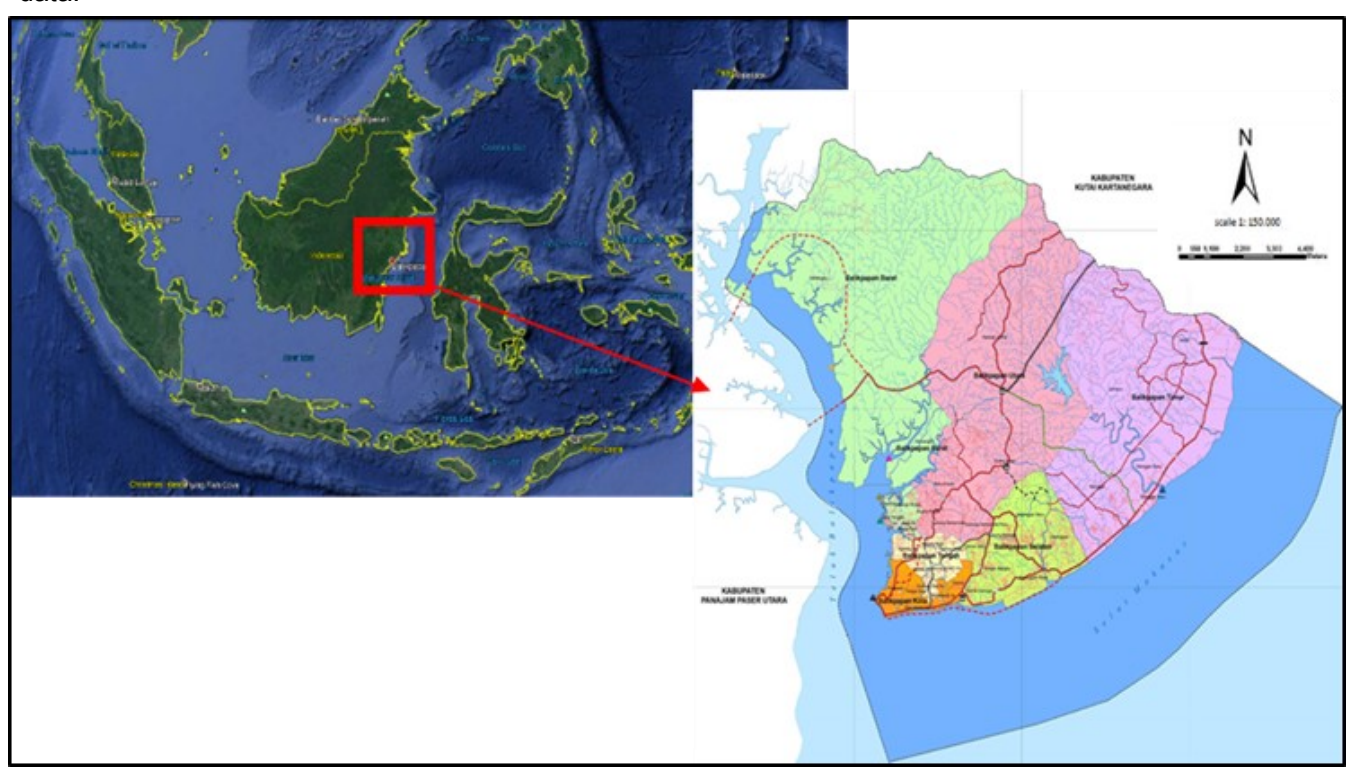

Fig. 1 - Balikpapan City as study area

Source: Google Maps and the Spatial Planning Agency of Balikpapan

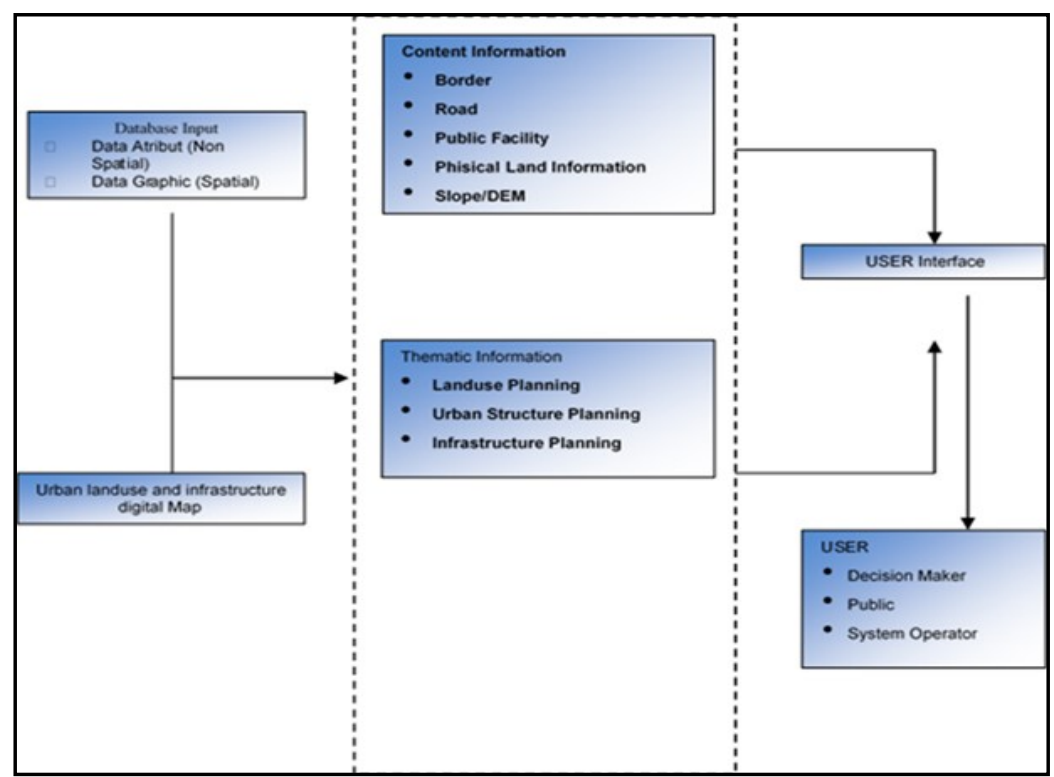

Fig. 2 - Web GIS module content information 
Web-based GIS applications are built using Quantum GIS merging and open source software, including the Linux Operating System, Mapserver, PHP/Mapscript, and Pmapper framework. The facilities contained in this GIS application are: (1) Users can open apps from the web, so they can view thematic maps that include the basic map, infrastructure, and land use maps, (2) Users can select the desired legend/layer, (3) Users can customize the map size by zooming in on the map layout, (4) Users can search by the search option, and (5) Users can view the information through the info table view. The framework of the information module is as shown in Fig. 2, while the input data in this system can be seen in Table 1.

Data Input for Web GIS

Table1

\begin{tabular}{|l|l|l|}
\hline Data & Type & Attribute data \\
\hline \multirow{4}{*}{ Spatial } & Road/Line (Vector) & Name of road, Length \\
\cline { 2 - 3 } & Administrative border / Polygon (vector) & $\begin{array}{l}\text { Name of Area } \\
\text { Area }\end{array}$ \\
\cline { 2 - 3 } & $\begin{array}{l}\text { Shapefile Land use existing and land use } \\
\text { planning (vector Polygon) }\end{array}$ & Name of land use \\
\cline { 2 - 3 } & Shapefile of infrastructure map & Area \\
\hline Non-Spatial & Image of location & Point location and coordinates \\
\hline
\end{tabular}

\section{User interface concept}

To create a stable and reliable web-based system which can be used properly, the design of the system must first be considered. Its design is formed using the concept of multi-users. The concept diagram in Fig. 3 shows the process flow in demand by the users, with the request and receive/view processes in one region. The accommodated processes in this user interface are: (1) the initial process provides requests through the browser, with a selection of available legend layers, (2) the request is accepted by the webserver, in this case forwarded to the Mapserver application which processes spatial data, i.e. file maps, (3) the map file is returned in the form of an image accompanied by an HTML template, and (4) it then determines the desired information by zooming and query on the map on the browser side. When the information obtained by searching the location, or directly from the zooming/pan, is final, then the process ends. In the interaction between the users, the web browsers (client) and the server are divided into several classes. Each class has its own operation. The MapObj class is the part structure of the file with a .map extension, which has the major class. They are: legendObj, scalebarObj, referencemapObj, outputObj, layerObj, querymap, and webObj.

\section{Results}

Web GIS Balikpapan (beta version) was developed in Bahasa Indonesia. Thus, in some discussions, an explanation in English will be added. There is an agreement between researchers and the local government that infrastructure data and land use should only be displayed in Bahasa Indonesia. Web GIS Balikpapan's development results can show all data for the consumption of policymakers and the wider community. In accordance with the principle of open data (Danneels et al. 2017, Ruijer et al. 2017), the information submitted must support democracy in policymaking and benefit the quality of life in the community.

Furthermore, the forms of the information displayed are in the form of a combination of spatial data in digital map form as well as a data attribute in tabular form, as in Fig. 4. In detail, the concept of open data initiated in Web GIS Balikpapan is open information spatial data, so that each unit of data layer displays information according to the existing condition. This is in accordance with the idea of open data for democracy and good governance (Mccall 2003, Lv et al. 2017, Oliveira et al. 2017, Sadiq and Indulska 2017), where transparent data, especially in 
Open-Source Web GIS Framework in Monitoring Urban Land Use Planning: Participatory Solutions for Developing Countries

the implementation of development, has an impact on the level of public trust in the government.

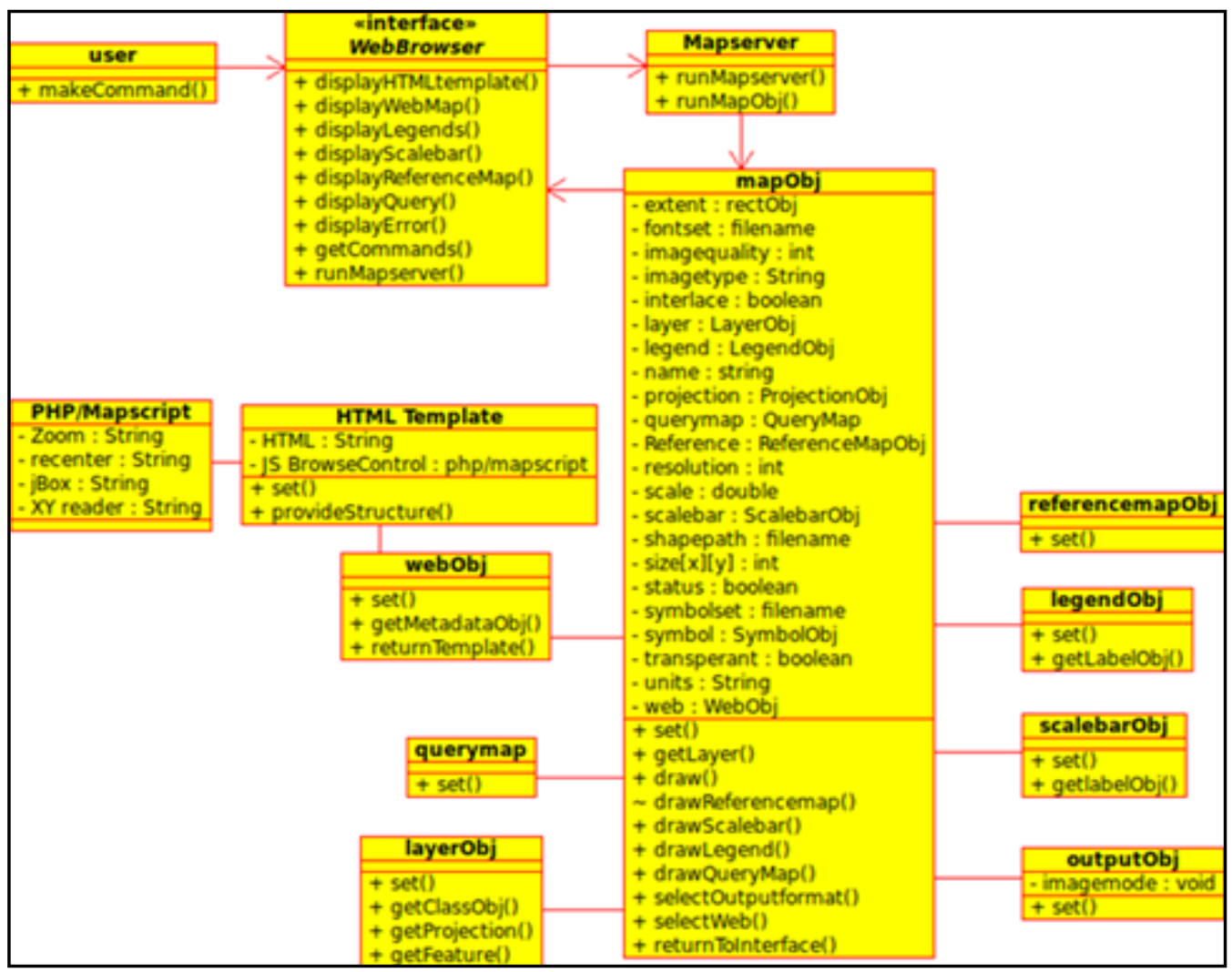

Fig. 3 - User interface concept diagram

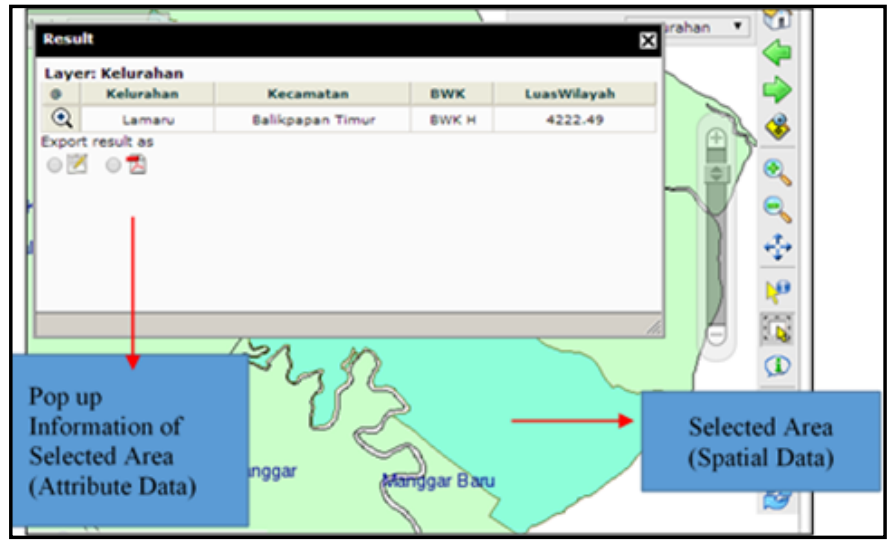

Fig. 4 - Open Data in Web GIS, a combination of spatial and tabular data 


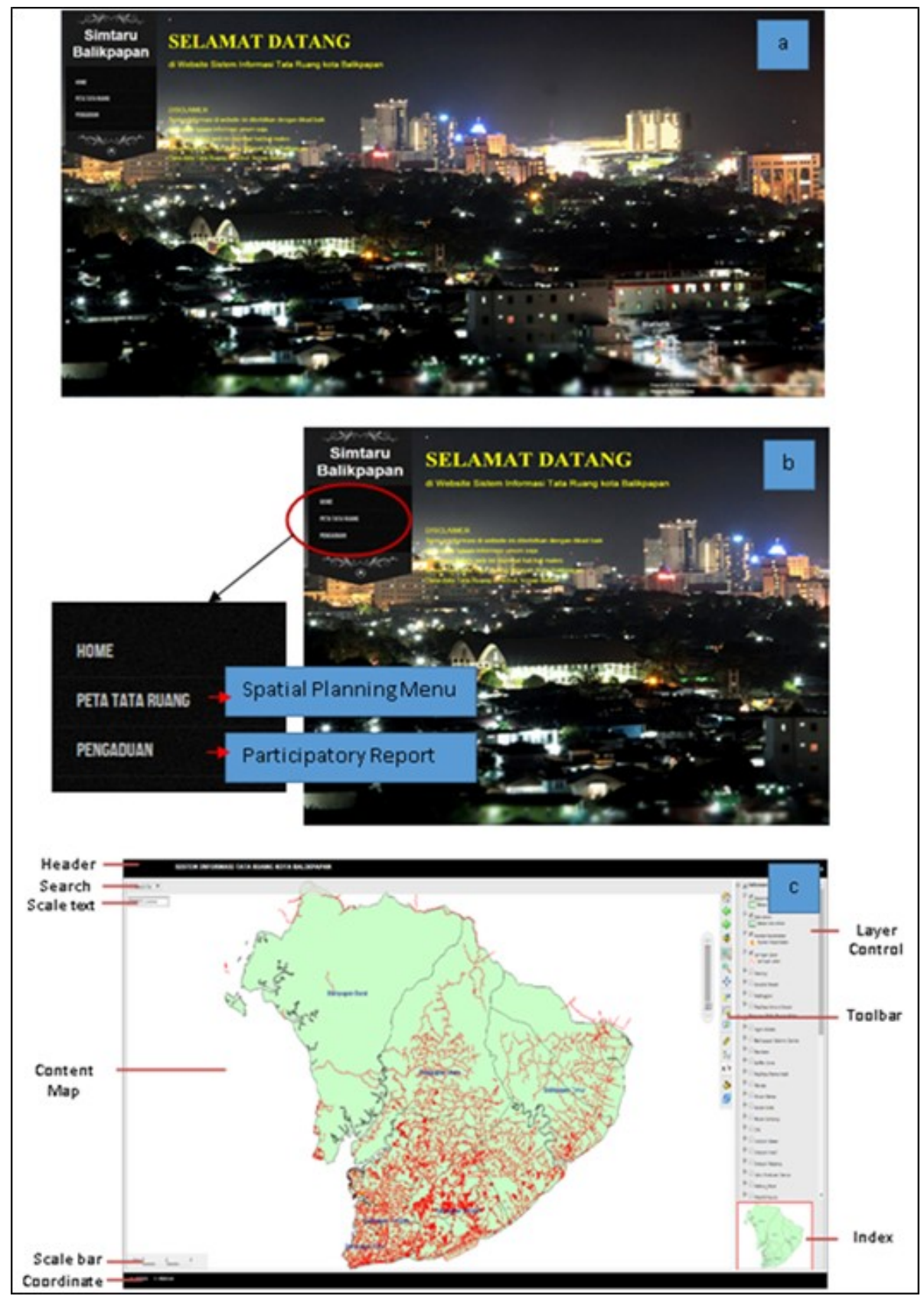

Fig. 5 - (a) Web User Interface, (b) Web Menu, (c) Web GIS Description System 
In terms of the use of the user interface, some menus are provided to facilitate users in accessing the data. The menu includes (1) home, (2) spatial planning menu, (3) infrastructure planning menu, (4) search menu, and (5) report and tag point menu. The menus in Balikpapan's Web GIS are a little different from the standard menu in the Web GIS software developed for disasters (Dong et al. 2013, Thiebes et al. 2013, Fago et al. 2014). However, by upholding the principle of open data, Balikpapan's Web GIS menus not only facilitate inputting or reporting not only from the operator system but also provide an opportunity for the public to report on the implementation of infrastructure development and land use (Fig. 5). Hence, the display data on Balikpapan's Web GIS is sourced from two directions, namely from government-appointed operators, and from the public. This two-way open data principle is in line with the smart governance principles - data transparency and participatory data - so that people can contribute with data on regional development (Mccall 2003, Voss et al. 2004, Awoleye et al. 2014).

\section{Discussion}

\section{Web GIS as supporting tools for monitoring urban land use planning}

It is not easy to formulate a procedure for monitoring the implementation of land use planning policy, especially in a multi-sector and multi-planning field. The system should be able to define the involved parts and explain the job description of each user. In Balikpapan Web GIS, the system is able to unify multiple planning databases from multiple sectors to bridge multiplanning needs, and thus it requires unified data from multiple sectors for the same needs (Bíl et al. 2012, Zhou et al. 2017). The sectors are land use planning and infrastructure for the same purpose of regional development planning. Moreover, the concept of smart governance should be able to bridge communications between the public and the government (Eom et al. 2016, Lv et al. 2017) so that Balikpapan Web GIS becomes an effective communication medium.

The framework for Balikpapan Web GIS emphasizes the effectiveness of communication between the government, as planning policymakers, and the community, as users and planning objects. The user definitions are made separately so that each party can perform varying functions and activities according to the procedure (Fig. 6). These are: (1) user operator-mediated duties in in-outing data, and as a moderator of data input from the community, (2) government users and policymakers in charge of disseminating planning policy products with accurate data in accordance with local regulations, (3) public users, who have access rights to view the overall planning data, including land use plans and infrastructure as a basis for development in their respective areas. The integration of these three users is facilitated in one system so that the unified data concept (Bíl et al. 2012) works well.

After understanding these activities, the public user will obtain their rights, namely data about the planning and obligation in assisting the government to do participatory monitoring of the implementation of the development plan. The complete public facility display can be seen in Fig. 7. The complete land use data are divided by each layer of land use. Similarly, infrastructure data are also displayed in the form of digital maps and data attributes. Land use planning data are useful to apply for a development permit for the community, as well as the data on infrastructure development plans.

The reporting facility (Fig. 8) provided by Web GIS Balikpapan as a participatory monitoring function is beneficial in the implementation of land use planning, so as to reduce the violation of land use. The participatory monitoring system effectively guards the development process (Voss et al. 2004, Dunn 2007, Nackoney et al. 2013, Mialhe et al. 2015). This concept is in line with Kovacs et al. (2017), who stated that the principles of democracy and the contribution or 
involvement of stakeholders (community and government) strongly influence the effectiveness of land use management. Furthermore, proper land use and infrastructure should be based on community demand (Hessel et al. 2009, Wellman and Spiller 2012, Derr et al. 2013, Breuste et al. 2015, Mathey et al. 2015), so that the concept of a smart city supported by technology can be a sustainable city (Ahvenniemi et al. 2017), complete with community involvement using Web GIS.

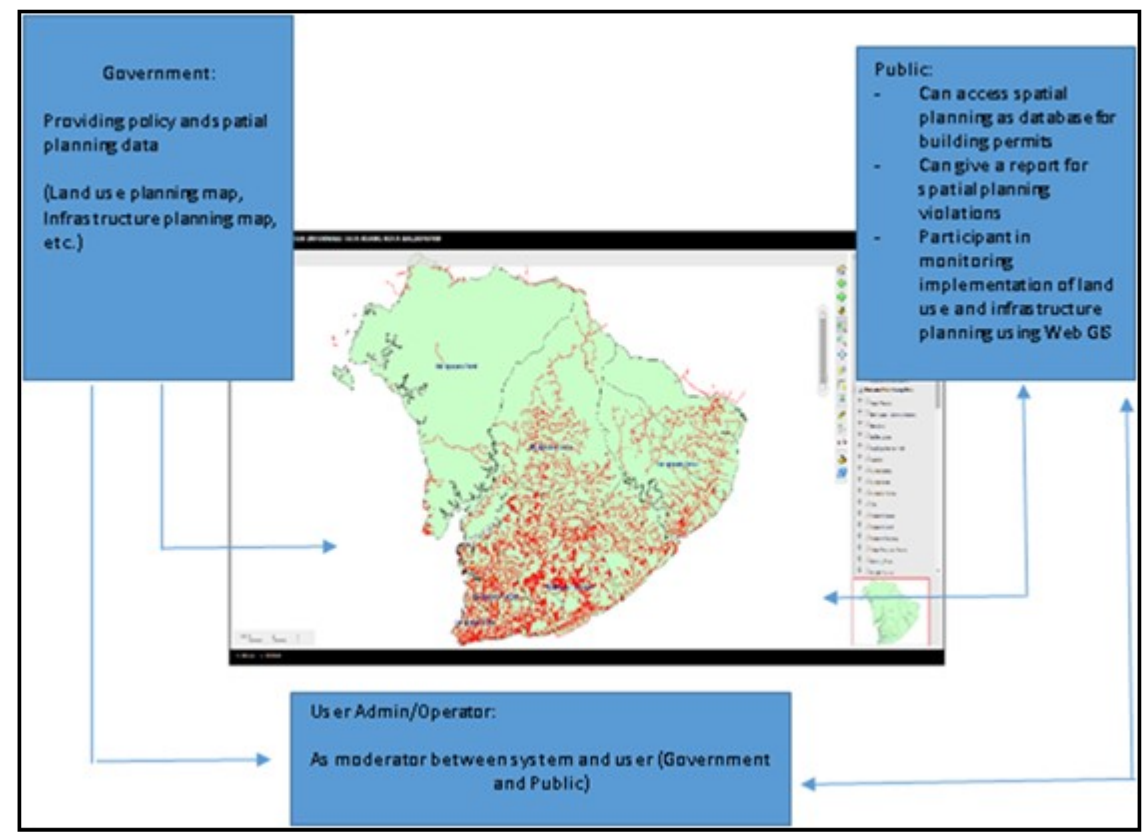

Fig. 6 - User job description in the Balikpapan Web GIS Framework

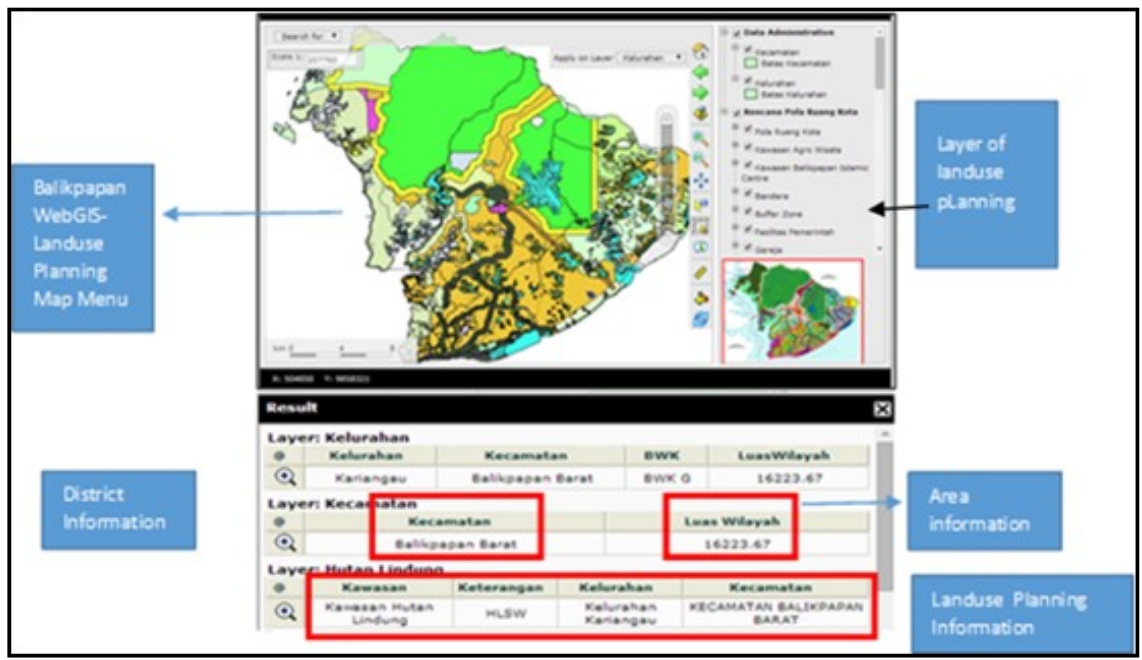

Fig. 7 - User facilities and information 


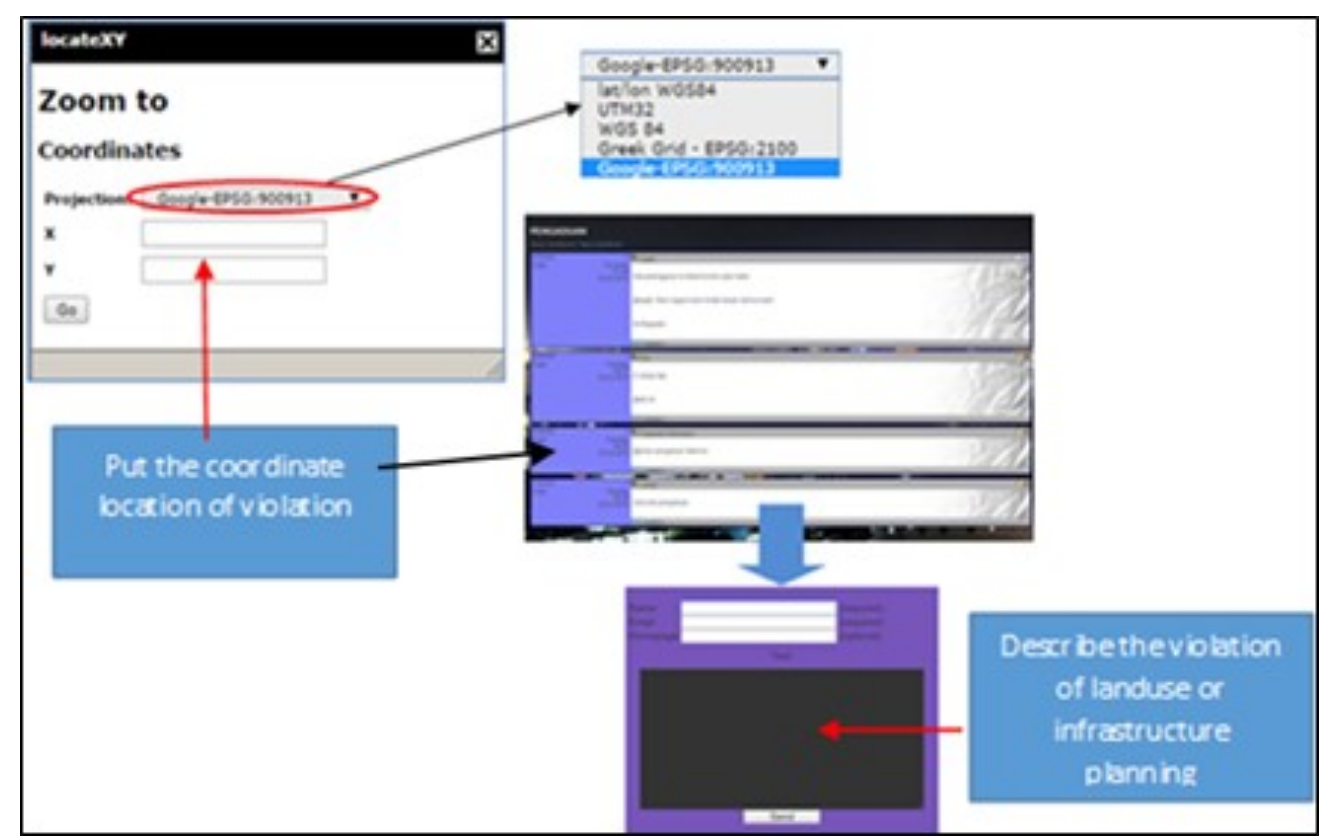

Fig. 8 - Reporting facility for monitoring land use planning violations

Looking at the workings and distribution patterns of both spatial and non-spatial databases, the Balikpapan Web GIS function is basically the same as Web GIS developed in previous studies (Pessina and Meroni 2009, Dong et al. 2013, Thiebes et al. 2013, Currenti et al. 2014, Fago et al. 2014, Grecea et al. 2016, Stanković et al. 2016), with various advantages that became the goal of making Web GIS. The benefits of the previous system are the early warning applications for disasters and the disaster history display in an area, while Balikpapan Web GIS can be used in the case of participatory monitoring to prevent land use and infrastructure planning.

In the GIS participatory process, the community's demands become the main point, especially in conveying information (Voss et al. 2004, Brown et al. 2017). The ease of delivering and receiving information responses is the critical factor to GIS participation so that the performance of the built system must match the needs of the users. From several tests conducted using a Focus Group Discussion (FGD) method intended to test Web GIS Balikpapan, one weakness which was found was that access time increases in line with an increasing number of users. The FGD invited representatives from each district in Balikpapan (25 users) to test the system usage. When ten users used the Balikpapan Web GIS, the access time was $3.6 \mathrm{~s}$, but when 20 to 25 users used it simultaneously, the access time increased to $6.4 \mathrm{~s}$ and $8.1 \mathrm{~s}$ (Fig. 9). This is an important note because, in real application, many users will access the system at the same time. Hence, it is necessary to strengthen the access to the system, so that the loading time is not too long, and it is lightly used. This weakness will be part of future work when the system is implemented in Balikpapan City.

Overall, the framework is in line with the needs of the community, both from the availability of land use information and motivating the community to be involved in monitoring the implementation of land use and infrastructure planning policy. When the system is implemented, there must be some adjustments in particular to improve the system 
performance, such as strengthening the server capacity for data access so that the system is convenient to use and it provides many benefits.

Furthermore, the system developed by Balikpapan Web GIS is more focused on supporting systems to assist the government in a participatory way. With the right communication approach through Web GIS, both government and community can monitor even large areas well. A useful monitoring function with good technological support will enable smart governance so that the implementation of development plans can be safeguarded together. In accordance with the smart city spirit, a smart city is not only a utopian concept but also beneficial to the people living in it, and, in so doing, it can improve the quality of life and create good governance (Feltynowski 2015, Eom et al. 2016, Ahvenniemi et al. 2017, Fietkiewicz et al. 2017, Kim et al. 2017, Lv et al. 2017).

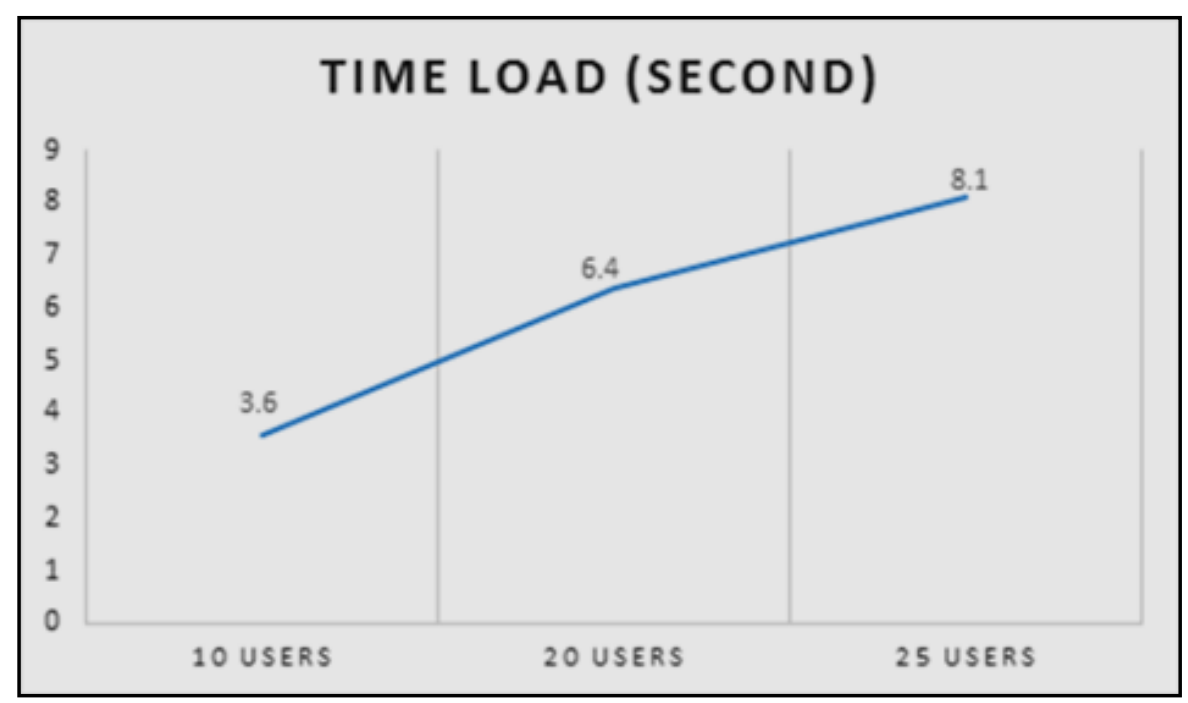

Fig. 9 - Time load to access Balikpapan Web GIS

The challenges in implementation

The problem of spatial planning is very complex and it requires the competence of experts from various fields and it involves policymakers with different interests. There is indeed no perfect solution for long-term spatial planning. However, the opportunities to improve the access to spatial information in support of participatory decision making need to be started as a solution in the future. In such circumstances, various parties are often involved, especially stakeholders who are directly involved in planning. They don't need to be GIS experts to be able to take advantage of Web GIS and to contribute to urban land use planning because it can be designed to be more user-friendly by utilizing open source technology and freeware.

Some debate did arise in the use of open-source software in web GIS. Most of the focus of the discussion is on the validity of copyright and data status. However, there have been many recommendations for open science projects using open-source software. We believe that free open source is not only understood as the free software but it also gives users the convenience and freedom to modify it. This is consistent with the study of Chmielewski et al. (2018) which indicates the importance of open access solutions to meet the expectations of volunteers and 
scientists, especially in developing GIS web in developing countries.

The impetus from theoretical discussions about spatial planning to include digital domains further strengthens the role of participation in urban and regional planning (Van Casteren and Sneyers 2002, Alam et al. 2018). Combining the two worlds in one planning job adds new options, especially in enhancing the planning tools. In this case, the network-based technology is designed to develop in increasing the satisfaction of all actors involved in urban and regional planning, especially in detecting the dynamics of urban land-use change. Space that initially existed only in the real world is currently developing in the virtual space that allows for spatial simulation and information in policymaking. Furthermore, this method will enable users to comment on selected features on the map, including comments as input for urban development and reports on violations of spatial use rules. If developed in more detail, this system can be an intermediary in interactive landscape planning, which is possible in helping spatial exploration in WebGIS.

From an academic perspective, web GIS Balikpapan tries to provide an example of using software with unlimited licenses. This is important, considering that some web GIS service providers with paid software are costly and must renew their licenses every year. This limitation can be overcome by open source web GIS with multiple support provided by the user community (QGIS, Map-Server, P-Mapper, Open Layers, Open Street Map, Leaflets). GIS communities are free to create and share their GIS tools. This activity is possible to spread open science methods to the public. In addition, this is also an initiative to utilize open source web GIS, especially in developing countries like Indonesia.

Aside from cost issues, another major problem is creating lightweight and portable web GIS solutions without additional costs such as purchasing additional licenses, changing the operating system or the hardware configuration. Typically, cloud-based mapping platforms such as this can display data interactively and it can describe land use, especially for monitoring in urban areas. Some contemporary Geoinformatics activists are also heading towards cloud services solutions. They are moving to get real-time data processing by adding several tools, but this system requires a complex system architecture. Thus, the choice to use web GIS-based on open source is the most realistic option to implement even though there are disadvantages such as being unable to provide real-time data.

In more complex challenges, Indonesia has also begun implementing spatial information systems through the one map policy program but it has not yet reached districts/cities outside of Java, so efforts to create web GIS with good spatial data in realizing smart governance are urgently needed. Institutional reform and spatial data management also promote a trend towards democratization of decision making using new technologies (Nackoney et al. 2013, Natarajan 2017, Ruijer et al. 2017). New technology is used to support the planning and control of land use, especially in decision making and monitoring the implementation of spatial plans. No platform perfectly facilitates these needs, but Web GIS development and efforts to implement it are an influential driving factor for the development of spatial data openness.

Limitations also appear as an integral part of the implementation. As a developing country, internet infrastructure in Indonesia, especially Balikpapan, continues to develop with varying capacities. Unstable internet connections are the main obstacle because Web GIS performs reliable management and analysis of information when the connection is well connected. However, the spatial dimension plays a substantive role in understanding given phenomena and estimating possible scenarios, especially for certain cities outside of Java. Indeed, Web GIS alone cannot solve all problems in the planning process, but their integration with policymakers and digital infrastructure is able to offer a solution towards smart government. 


\section{Conclusions}

Based on the results of the study, Web GIS development Balikpapan can assist the realization of smart governance. Built applications do not always have expensive costs, and as with the use of open source technology in the construction of Balikpapan Web GIS, the cost can be reduced. Furthermore, open-source Web GIS provides opportunities to develop many features that can help to bridge communications between government and communities in monitoring the implementation of land use and infrastructure planning policy. Some system adjustments for future work should be made, especially regarding the speed of access when multiple persons use it; therefore, future work is required for the development of system performance. Thus, it will facilitate communication between the community and the government.

With excellent communication and open data support between Web GIS system, government, and society, smart city implementation with smart people and smart governance will no longer be a utopian ideal. Moreover, further research needs to be done. One of them is researching the response of urban communities at all levels in using web GIS technology. This is important because urban communities are the subject and object of using Web GIS technology in land use monitoring systems. By doing so, this technology can be sustainable and useful to be implemented in all developing countries.

\section{Acknowledgments}

The authors would like to thank the Planning and Development Agency of Balikpapan, East Borneo for supporting this research. This article's publication is partially supported by the United States Agency for International Development (USAID) through the Sustainable Higher Education Research Alliance (SHERA) Program for Universitas Indonesia's Scientific Modeling, Application, Research and Training for City-centered Innovation and Technology (SMART CITY) Project, Grant \#AID-497-A-1600004, Sub Grant \#IIE-00000078-UI-1.

\section{References}

AHVENNIEMI H., HUOVILA A., PINTO-SEPPÄ I., AIRAKSINEN M. (2017), What are the differences between sustainable and smart cities?, Cities 60 (Part A), 234-245.

AINA Y. A. (2017), Achieving smart sustainable cities with GeolCT support: The Saudi evolving smart cities, Cities 71, 49-58.

ALAM K., ERDIAW-KWASIE M. O., SHAHIDUZZAMAN M., RYAN B. (2018), Assessing regional digital competence: Digital futures and strategic planning implications, Journal of Rural Studies 60, 60-69.

ANTHOPOULOS L. (2017), Smart utopia VS smart reality: Learning by experience from 10 smart city cases, Cities 63, 128-148.

AWOLEYE O. M., OJULOGE B., ILORI M. O. (2014), Web application vulnerability assessment and policy direction towards a secure smart government, Government Information Quarterly 31 (S1), S118-S125.

BÍL M., BÍLOVÁ M., KUBEČEK J. (2012), Unified GIS database on cycle tourism infrastructure, Tourism Management 33 (6), 1554-1561.

BREUSTE J., ARTMANN M., LI J., XIE M. (2015), Special Issue on Green Infrastructure for Urban Sustainability, Journal of Urban Planning and Development 141 (3), A2015001.

BROWN G., STRICKLAND-MUNRO J., KOBRYN H., MOORE S. A. (2017), Mixed methods participatory GIS: An evaluation of the validity of qualitative and quantitative mapping methods, Applied Geography 79, 153-166.

BUCHORI I., SUGIRI A., HADI S. P., WADLEY D., LIU Y. (2015a), Developing a geographic information system-based assessment model for sustainable metropolitan development: The case of the Semarang Metropolitan Region, Indonesia, American Journal of 
Environmental Sciences 11 (2), 62-75.

BUCHORI I., YUSUF M. B. A., SEJATI A. W., SUGIRI A. (2015b), Rancang Bangun Sistem Informasi Keruangan Berbasis Web-Sistem Informasi Geografis (SIG) Untuk Pembangunan Metropolitan Berkelanjutan Studi Kasus: Wilayah Metropolitan Semarang, Seminar Nasional Tata Ruang Dan Space\# 2, 260-276.

BUCHORI I., PRAMITASARI A., SUGIRI A., MARYONO M., BASUKI Y., SEJATI A. W. (2018), Adaptation to coastal flooding and inundation: Mitigations and migration pattern in Semarang City, Indonesia, Ocean \& Coastal Management 163, 445-455.

BUCHORI I., SUGIRI A. (2016), An empirical examination of sustainable metropolitan development in Semarang City, Indonesia, Australian Planner 53 (3), 163-177.

BUCHORI I., TANJUNG K. (2014), Developing a Simulation Model for Predicting Inundated Areas Affected by Land Use Change: A Case Study of Keduang Sub-watershed, The International Journal of Environmental Sustainability 9 (1), 79-108.

BURGER A. (2009), P.mapper: A MapServer PHP/MapScript Framework, Retrieved from: www.pmapper.net.

CHMIELEWSKI S., SAMULOWSKA M., LUPA M., LEE D., ZAGAJEWSKI B. (2018), Citizen science and WebGIS for outdoor advertisement visual pollution assessment, Computers, Environment and Urban Systems 67, 97-109.

CURRENTI G., NAPOLI R., SICALI A., GRECO F., DEL NEGRO C. (2014), GEOFIM: A WebGIS application for integrated geophysical modeling in active volcanic regions, Computers \& Geosciences 70, 120-127.

DANNEELS L., VIAENE S., VAN DEN BERGH J. (2017), Open data platforms: Discussing alternative knowledge epistemologies, Government Information Quarterly 34 (3), 365-378.

DERR V., CHAWLA L., MINTZER M., CUSHING D. F., VAN VLIET W. (2013), A City for All Citizens: Integrating Children and Youth from Marginalized Populations into City Planning, Buildings 3, 482-505.

DONG S., WANG X., YIN H., XU S., XU R. (2013), Semantic enhanced WebGIS approach to visualize Chinese historical natural hazards, Journal of Cultural Heritage 14 (3), 181-189. $-637$.

DUNN C. E. (2007), Participatory GIS - a people's GIS?, Human Geography 31 (5), 616

ELMANISA A., KARTIVA A., FERNANDO A., ARIANTO R., WINARSO H., ZULKAIDI D. (2017), Land price mapping of Jabodetabek, Indonesia, Geoplanning: Journal of Geomatics and Planning 4 (1), 53-62.

EOM S.-J., CHOI N., SUNG W. (2016), The use of smart work in government: Empirical analysis of Korean experiences, Government Information Quarterly 33 (3), 562-571.

FAGO P., PIGNATELLI C., PISCITELLI A., MILELLA M., VENERITO M., SANSÒ P., MASTRONUZZI G. (2014), WebGIS for Italian tsunami: A useful tool for coastal planners, Marine Geology 355, 369-376.

FELTYNOWSKI M. (2015), Spatial information systems - a tool supporting good governance in spatial planning processes of green areas, Journal of Urban and Regional Analysis 7 (1), 69-82.

FIETKIEWICZ K. J., MAINKA A., STOCK W. G. (2017), eGovernment in cities of the knowledge society. An empirical investigation of Smart Cities' governmental websites, Government Information Quarterly 34 (1), 75-83.

GIL-GARCIA J. R., ZHANG J., PURON-CID G. (2016), Conceptualizing smartness in government: An integrative and multi-dimensional view, Government Information Quarterly 33 (3), 524-534.

GKATZOFLIAS D., MELLIOS G., SAMARAS Z. (2013), Development of a web GIS application for emissions inventory spatial allocation based on open source software tools, Computers \& Geosciences 52, 21-33

GRECEA C., HERBAN S., VILCEANU C.-B. (2016), WebGIS Solution for Urban 
Planning Strategies, Procedia Engineering 161, 1625-1630. 79-85.

GROSSI G., PIANEZZI D. (2017), Smart cities: Utopia or neoliberal ideology?, Cities 69,

HESSEL R., VAN DEN BERG J., KABORÉ O., VAN KEKEM A., VERZANDVOORT S., DIPAMA J.-M., DIALLO B. (2009), Linking participatory and GIS-based land use planning methods: A case study from Burkina Faso, Land Use Policy 26 (4), 1162-1172.

KIM T.-H., RAMOS C., MOHAMMED S. (2017), Smart City and loT, Future Generation Computer Systems 76, 159-162.

KOVACS E., KELEMEN E., KISS G., KALÓCZKAI Á., FABÓK V., MIHÓK B., MEGYESI B., PATAKI G., BODORKÓS B., BALÁZS B., BELA G., MARGÓCZI K., ROBOZ Á., MOLNÁR D. (2017), Evaluation of participatory planning: Lessons from Hungarian Natura 2000 management planning processes, Journal of Environmental Management 204 (Part 1), 540550.

KUMMITHA R. K. R., CRUTZEN N. (2017), How do we understand smart cities? An evolutionary perspective, Cities 67, 43-52.

LV Z., LI X., WANG W., ZHANG B., HU J., FENG S. (2018), Government affairs service platform for smart city, Future Generation Computer Systems 81, 443-451.

MATHEY J., RÖßLER S., BANSE J., LEHMANN I. (2015), Brownfields As an Element of Green Infrastructure for Implementing Ecosystem Services into Urban Areas, Journal of Urban Planning and Development 141 (3), A4015001.

MCCALL M. K. (2003), Seeking good governance in participatory-GIS: a review of processes and governance dimensions in applying GIS to participatory spatial planning, Habitat International 27 (4), 549-573.

MIALHE F., GUNNELL Y., IGNACIO J. A. F., DELBART N., OGANIA J. L., HENRY S. (2015), Monitoring land-use change by combining participatory land-use maps with standard remote sensing techniques: Showcase from a remote forest catchment on Mindanao, Philippines, International Journal of Applied Earth Observation and Geoinformation 36, 69-82.

MÜLLER M. F., THOMPSON S. E., KELLY M. N. (2016), Bridging the information gap: A webGIS tool for rural electrification in data-scarce regions, Applied Energy 171, 277-286.

NACKONEY J., RYBOCK D., DUPAIN J., FACHEUX C. (2013), Coupling participatory mapping and GIS to inform village-level agricultural zoning in the Democratic Republic of the Congo, Landscape and Urban Planning 110, 164-174.

NAKAYAMA Y., NAKAMURA K., SAITO H., FUKUMOTO R. (2017), A Web GIS Framework for Participatory Sensing Service: An Open Source-Based Implementation, Geosciences 7 (2), 1-15.

NASARUDDIN N., MUNADI K., DIRHAMSYAH M., YULIANSYAH D. (2011), A webbased geographic information system for aceh natural hazards, TELKOMNIKA 9 (1), 89-98.

NATARAJAN L. (2017), Socio-spatial learning: A case study of community knowledge in participatory spatial planning, Progress in Planning 111, 1-23.

NIAROS V., KOSTAKIS V., DRECHSLER W. (2017), Making (in) the smart city: The emergence of makerspaces, Telematics and Informatics 34 (7), 1143-1152.

OLIVEIRA J., DELGADO C., ASSAIFE A. C. (2017), A recommendation approach for consuming linked open data, Expert Systems with Applications 72, 407-420.

PESSINA V., MERONI F. (2009), A WebGis tool for seismic hazard scenarios and risk analysis, Soil Dynamics and Earthquake Engineering 29 (9), 1274-1281.

PURWANTO A., BAYUARDI G. (2016), Monitoring the Land Use Change in Campus 2 STKIP PGRI Pontianak, Geoplanning: Journal of Geomatics and Planning 3 (1), 77-86.

RUIJER E., GRIMMELIKHUIJSEN S., MEIJER A. (2017), Open data for democracy: Developing a theoretical framework for open data use, Government Information Quarterly 34 (1), 45-52.

SADIQ S., INDULSKA M. (2017), Open data: Quality over quantity, International Journal of Information Management 37 (3), 150-154.

SEJATI A. W., BUCHORI I., RUDIARTO I. (2018), The Impact of Urbanization to Forest 
Degradation in Metropolitan Semarang: A Preliminary Study, IOP Conference Series: Earth and Environmental Science 123, 012011.

SEJATI A. W., BUCHORI I., RUDIARTO I. (2019), The Spatio-Temporal Trends of Urban Growth and Surface Urban Heat Islands over Two Decades in the Semarang Metropolitan Region, Sustainable Cities and Society 46, 101432.

SEJATI A. W., RAMADHAN M. (2015), Pemantauan Implementasi Rencana Tata Ruang Berbasis WebGIS untuk Identifikasi Lahan Kritis, CoUSD-1, 246-253.

STANKOVIĆ R., VULOVIĆ N., LILIĆ N., OBRADOVIĆ I., TOŠOVIĆ R. (2016), A WebGIS Decision Support System for Management of Abandoned Mines, Energies 9, 567.

TARIGAN A. K. M., SAMSURA D. A. A., SAGALA S., WIMBARDANA R. (2017), Balikpapan: Urban planning and development in anticipation of the post-oil industry era, Cities 60 (Part A), 246-259.

THIEBES B., BELL R., GLADE T., JÄGER S., ANDERSON M., HOLCOMBE L. (2013), A WebGIS decision-support system for slope stability based on limit-equilibrium modelling, Engineering Geology 158, 109-118.

VAN CASTEREN J., SNEYERS S. (2002), The use of digital information in a municipal spatial structure plan, CORP, 395-400.

VOSS A., DENISOVICH I., GATALSKY P., GAVOUCHIDIS K., KLOTZ A., ROEDER S., VOSS H. (2004), Evolution of a participatory GIS, Computers, Environment and Urban Systems 28 (6), 635-651.

WELLMAN K., SPILLER M. (eds.) (2012), Urban Infrastructure: Finance and Management, Wiley, Oxford.

WIRKUS L. (2015), An Open Source WebGIS Application for Civic Education on Peace and Conflict, ISPRS International Journal of Geo-Information 4, 1013-1032.

ZHOU X., LU X., LIAN H., CHEN Y., WU Y. (2017), Construction of a Spatial Planning system at city-level: Case study of "integration of multi-planning" in Yulin City, China, Habitat International 65, 32-48.

Initial submission: 23.01.2019

Revised submission: 01.09.2019

Final acceptance: 22.10 .2019

Correspondence: Department of Urban and Regional Planning, Center of Geomatics Application for Sustainable Development (CEGAS), Diponegoro University Jl. Prof. Soedarto, SH Tembalang, Semarang, 1269, Indonesia.

Email: anang@live.undip.ac.id 
